\title{
Structure of the phytoplankton community in the Cachoeira Dourada reservoir (GO/MG), Brazil
}

\author{
Teixeira de Oliveira, M. ${ }^{a *}$, Rocha, $O .^{b}$ and Peret, $A C{ }^{c}$

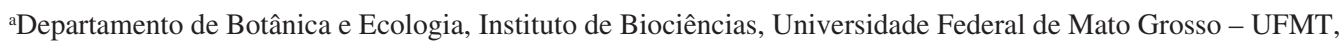 \\ Av. Fernando Correia da Costa, 2367, Boa Esperança, CEP 78060-900, Cuiabá, MT, Brazil \\ bDepartamento de Ecologia e Biologia Evolutiva, Universidade Federal de São Carlos - UFSCar, \\ Rod. Washington Luis, Km 235, CEP 13564-905, São Carlos, SP, Brazil \\ ${ }^{\mathrm{c}}$ Departamento de Hidrobiologia, Universidade Federal de São Carlos - UFSCar, \\ Rod. Washington Luis, Km 235, CEP 13564-905, São Carlos, SP, Brazil \\ *e-mail: marciatoli@yahoo.com.br
}

Received May 19, 2010 - Accepted September 8, 2010 - Distributed August 31, 2011

(With 4 figures)

\begin{abstract}
The limnological features and the phytoplankton community of the Cachoeira Dourada reservoir were analyzed in December 2006, May 2007 and November 2007. Temporal changes in the taxonomic composition, density, diversity and dominance of species were analyzed in relation to climatic factors and the physical and chemical characteristics of the water. A positive correlation was found between some of the physical and chemical variables and the phytoplankton community. According to the $\mathrm{CCA}$, variables such as the extent of the euphotic zone, temperature, $\mathrm{pH}$, nitrogen and phosphorus concentrations directly affected the phytoplankton dynamics. Organisms belonging to the class Cyanophyceae were the most representative in all the sampling periods, comprising the functional groups $\mathrm{K}, \mathrm{S} 1, \mathrm{M}$ and $\mathrm{H}$. Hydrodynamics and seasonal fluctuations of environmental factors were the driving forces determining the composition and abundance of the algal assemblages. Despite the prevalence of Cyanobacteria, the reservoir is still oligotrophic. The absence of blooms and the relatively low population abundances indicated that the quality of the reservoir's water still lies within the limits required for its multiples uses.
\end{abstract}

Keywords: Cachoeira Dourada, phytoplankton ecology, tropical reservoir, algal community.

\section{Estrutura da comunidade fitoplanctônica do reservatório de Cachoeira Dourada, GO/MG, Brasil}

\begin{abstract}
Resumo
As características limnológicas e a comunidade fitoplanctônica do reservatório de Cachoeira Dourada foram analisadas nos meses de dezembro de 2006, maio de 2007 e novembro de 2007. As flutuaç̃os temporais na composição taxonômica, densidade, diversidade e dominância de espécies foram analisadas em relação aos fatores climáticos e às variáveis físicas e químicas da água. Uma correlação positiva foi encontrada entre algumas das variáveis físicas e químicas analisadas e a comunidade fitoplanctônica. De acordo com a CCA, variáveis como a extensão da zona eufótica, temperatura, $\mathrm{pH}$, nitrogênio e fósforo influenciaram diretamente na dinâmica do fitoplâncton. Organismos pertencentes à classe Cyanophyceae foram as mais representativas em todos os períodos amostrais, abrangendo os grupos funcionais $\mathrm{K}$, S1, M e H. A hidrodinâmica e a variação sazonal dos fatores ambientais foram as forças determinantes da composição e abundância das assembleias de algas. Apesar do predomínio de cianobactérias, o ambiente do reservatório ainda é oligotrófico. A ausência de florações e as abundâncias populacionais relativamente baixas indicaram que a qualidade da água do reservatório continua se mantendo dentro dos limites estipulados para seus usos múltiplos.
\end{abstract}

Palavras-chave: Cachoeira Dourada, ecologia de fitoplâncton, reservatório tropical, comunidade algal. 


\section{Introduction}

River damming leads to modifications of the river's basic conditions and water dynamics. The hydrodynamic conditions established after the formation of reservoirs, allied to increased nutrient concentrations resulting from the decomposition of submerged vegetation and allochthonous input from upstream, favor algal development (Train et al., 2005) and the biomass thus produced may be exported to the stretch of river downstream (Silva et al., 2001).

Sediment and nutrient transport and river aeration are altered when a river's course is interrupted by a dam. The morphology of reservoirs causes longitudinal changes and modifies flow speeds, resulting in different mixing zone depths and altering the availability of light and nutrient concentrations, which, among other aspects, lead to the occurrence of vertical and horizontal gradients of abiotic factors and of the biotic communities of these systems (Kimmel et al., 1990). The impacts caused by dam construction, including public health problems due to environmental deterioration, are mainly related to the reservoir's size, volume and retention time, its geographic location, among other factors (Tundisi et al., 2002).

The phytoplankton community is one of the communities widely used as a tool for the evaluation of water quality (Costa et al., 1991; Prygiel, 1991). Phytoplankton comprises a wide variety of algae with different life histories and strategies to maximize productivity (Chellappa et al., 2009).

Studies of phytoplankton community ecology as an indicator of the trophic state of aquatic systems have been conducted in various Brazilian reservoirs. In 2001,
Rodrigues et al. (2005) evaluated indicator species of the trophic state and phytoplankton ecology in 30 reservoirs in the states of São Paulo and Paraná, Brazil.

In the last decade, significant advances have been made in understanding the ecology of phytoplankton communities in tropical reservoirs, as shown by the work of Silva et al. (2005), Fernandes et al. (2005) and Train et al. (2005). Furthermore, studies of a taxonomic nature (Brassac and Ludwig, 2003, 2005) and of the functional groups directly linked to physiological adaptations were conducted, allowing for a more effective prediction of environmental conditions. In tropical and subtropical regions, this approach has been applied by Kruk et al. (2002), Melo and Huszar (2000), Huszar et al. (2003), Crossetti and Bicudo (2005), Lopes et al. (2005), Borges et al. (2008), Gemelgo et al. (2009), among others. Based on the above, the objective of this work was to analyze the structure of the phytoplankton community and its functional groups as one of the tools to evaluate the environmental conditions of the Cachoeira Dourada reservoir.

\section{Material and Methods}

\subsection{Study area}

The hydrographic basin that feeds the dam of the Cachoeira Dourada GO/MG hydroelectric plant (HEP) (Figure 1) is located on the border between the states of Goiás and Minas Gerais, delimited by the UTM (Universal Transverse Mercator) coordinates 650,000 to $760,000 \mathrm{~m}$ and 7,910,000 to 7,965,000 $\mathrm{m}$ on the Topographic Map of

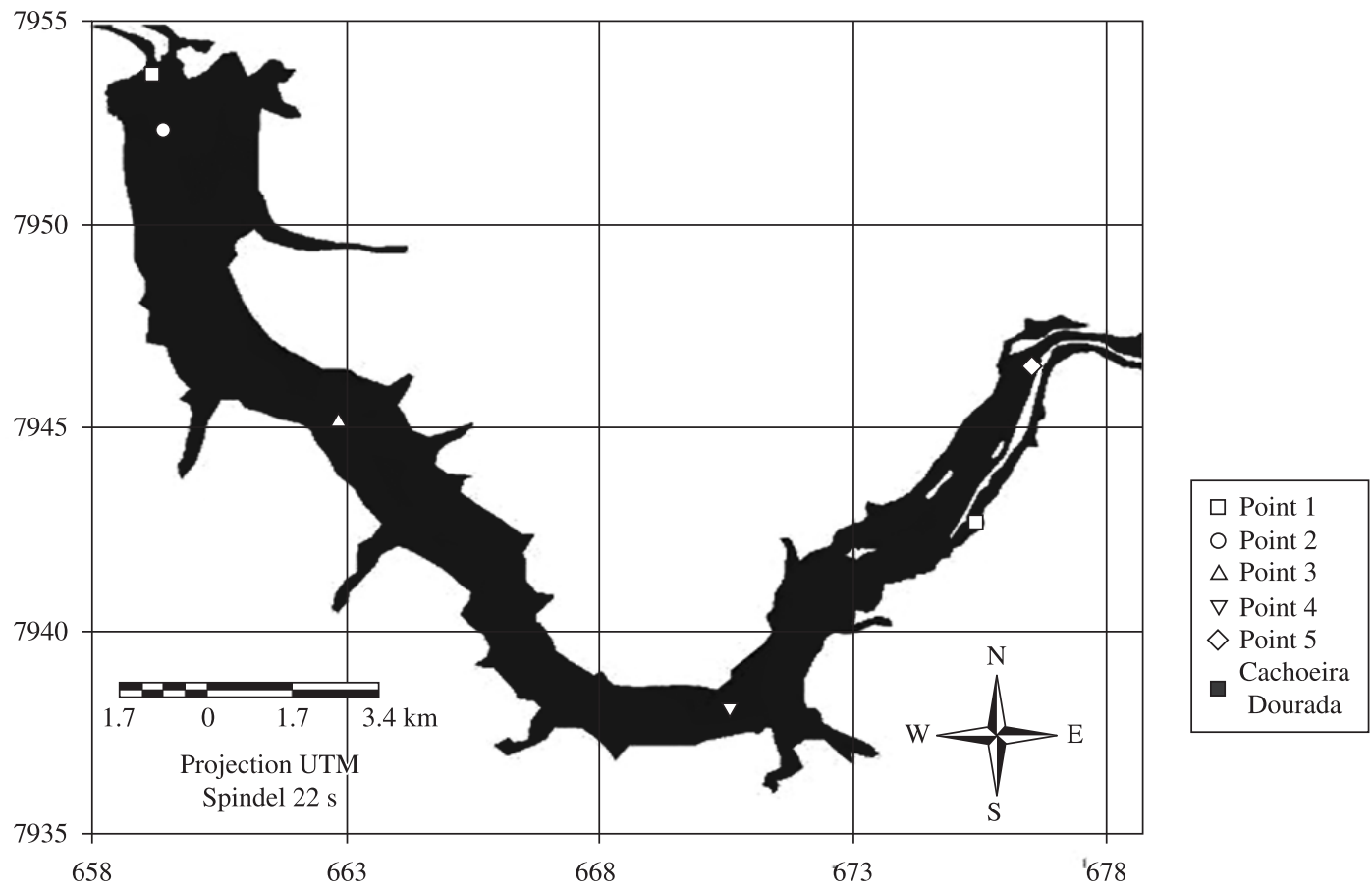

Figure 1. Map showing the location of the Cachoeira Dourada reservoir at the border between the states of Goiás and Minas Gerais (GO/MG), and map of the reservoir showing the 5 sampling sites of this study. 
Uberlândia on a scale of 1:250.000 (Cabral et al., 2005). The hydroelectric plant, which began operating in 1959 with the main purpose of generating electric power, is part of a complex of dams situated along the Paranaíba River. The reservoir has a capacity of 524,000.000 $\mathrm{m}^{3}$ and an average depth of $7.8 \mathrm{~m}$. Its drainage basin, which covers an area of 3,111 km², generates $635 \mathrm{MW}$ (Cabral et al., 2005) and extends over $65 \mathrm{~km}^{2}$ and is located predominantly in the municipality of Cachoeira Dourada (Figure 1).

The rainfall data were obtained from the National Institute for Space Research (INPE), SP.

\subsection{Sampling}

Phytoplankton samples were collected in December 2006 and May and November 2007 at five sampling points, four of them located in the reservoir at mean depths of $10.2 \mathrm{~m}$ (pt2), $7.03 \mathrm{~m}$ (pt3), $4.8 \mathrm{~m}$ (pt4) and $9.3 \mathrm{~m}$ (pt5) and one downstream at a mean depth of $16.6 \mathrm{~m} \mathrm{(pt1).}$ Fifteen samples were analyzed in each sampling period, corresponding to a total of three samples per sampling point, collected in triplicate. For the quantitative analysis of the phytoplankton, samples were collected using a Van Dorn bottle, fixed with $1 \%$ Lugol's acetic acid solution and stored in amber glass jars. The qualitative samples were collected by horizontal and vertical sweeps of a plankton tow net with $20 \mu \mathrm{m}$ holes; these samples were collected in triplicate to ensure the accuracy of the data. The samples were fixed in $2 \%$ formaldehyde and stored in polyethylene jars.

The variables of temperature, electrical conductivity, $\mathrm{pH}$, oxygen concentration, water transparency and depth were determined with an YSI 650MDS multiparameter probe. The extent of the euphotic zone was calculated by multiplying the Secchi disk readings by 3.0 (Esteves, 1998). The nutrients: total phosphorus, soluble phosphorus (Murphy and Riley, 1962), ammonia nitrogen (Koroleff, 1976); total nitrogen, nitrite and nitrate were determined in the laboratory according to Mackereth et al. (1978). Samples to evaluate physical and chemical variables were collected monthly from December 2006 to November 2007.

\subsection{Analysis of data}

Phytoplankton density was estimated according to the method described by Uthermöhl (1958) and APHA (1995). Individuals were counted in random fields and the specific biomass was estimated by multiplying the population density by the volume of individuals (Edler, 1979; Wetzel and Likens, 2000). The size categories (nano and micro) identified in the phytoplankton community followed the classification of Sieburth (1978).

The analysis of occurrence frequency $(\mathrm{F})(\%)$ was based on the classification proposed by Dajoz (1973). Diversity (H') was estimated by the Shannon-Wiener diversity index (Shannon and Weaver, 1963), and richness was considered the total number of taxa found per sample. Grouping of the species into different functional groups was based on the criteria suggested by Reynolds et al., (2002).
The set of abiotic data and the phytoplankton community were evaluated by canonical correspondence analysis (CCA). The biological matrix was built considering species abundance according to the criteria of Lobo and Leighton (1986). The Monte Carlo test was applied using the CANOCO 3.12 program to check the level of significance of the environmental parameters in the CCA (Ter Braak and Smilauer, 2002).

\section{Results}

The rainfall data indicated the existence of clearly distinct periods in terms of rainfall, i.e., a rainy period extending from November 2006 (spring) to March 2007, which was also characterized by higher temperatures and decrease of the extent of the euphotic zone. Sediment loaded into the reservoir reduced the $\mathrm{pH}$ and increased the concentrations of nitrogen and phosphorus compounds, making the water slightly acid and nutrient-enriched. The dry period lasted from April to October 2007 and was characterized by low concentrations of dissolved oxygen and electrical conductivity of the water (Figure 2 and Table 1).

During the period of this study, the concentrations of the phosphorus and nitrogen compounds in the Cachoeira Dourada reservoir were relatively low and did not exceed the limits established by the National Environmental Agency (CONAMA) for class 2 waters, despite the

increase in nitrogen that occurred in the rainy period and dissolved phosphorus in March and April 2007 (dry season).

\subsection{Phytoplankton composition}

In the three sampling periods, the total occurrence of 109 taxa was recorded, distributed among the classes Cyanophyceae (30), Zygnematophyceae (25), Chlorophyceae (24), and Bacillariophyceae (18), which together represented $88.99 \%$ of the community. The classes with the lowest representativeness were Euglenophyceae (4), Chrysophyceae (4), Xantophyceae (2), Dinophyceae and Cryptophyceae with 1 taxon each, jointly representing $11.01 \%$ of the phytoplankton community (Table 2).

Regarding the frequency of occurrence of taxa (Table 2), the phytoplankton consisted of 30 common taxa (10 Cyanophyceae, 05 Chlorophyceae, 04 Bacillariophyceae and 09 Zygnematophyceae, 01 Chrysophyceae and 01 Dinophyceae); 11 frequent taxa (05 Cyanophyceae, 03 Bacillariophyceae, 02 Euglenophyceae and 01 Zygnematophyceae); 60 rare taxa (15 Chlorophyceae, 15 Zygnematophyceae, 13 Cyanophyceae, 09 Bacillariophyceae, 03 Chrysophyceae, 02 Euglenophyceae, 02 Xantophyceae and 01 Cryptophyceae) and 08 constant taxa (02 Cyanophyceae, 04 Chlorophyceae and 02 Bacillariophyceae), as indicated in the data presented in Figure 3 and Table 2.

In terms of the size of phytoplankton organisms, nanophytoplankton ( 2 to $20 \mu \mathrm{m}$ ) represented on average $50.84 \%$ of the phytoplankton community and microphytoplankton $(20-200 \mu \mathrm{m}) 49.15 \%$. With respect to abundant taxa, there was a predominance of those 


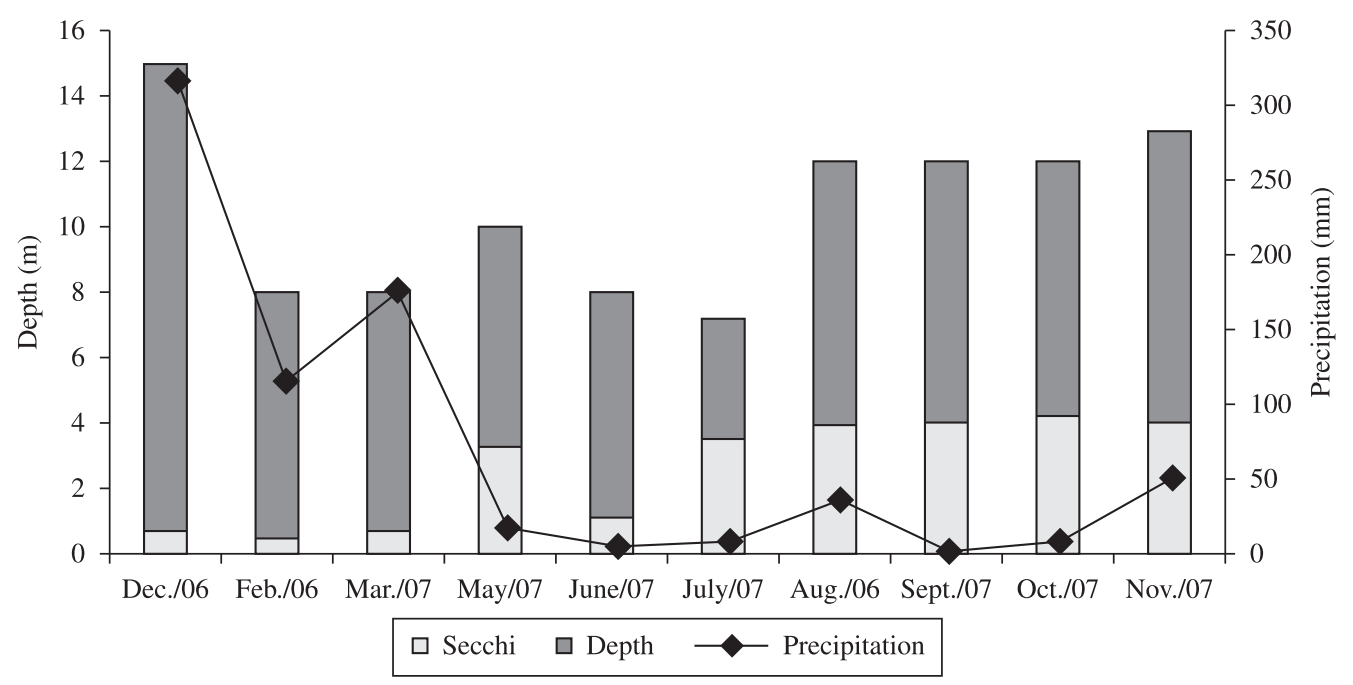

Figure 2. Variations in rainfall and depth (bar)and Secchi Disk transparencies (line) for Cachoeira Dourada Reservoir, GO/ MG, in the period between December 2006 and November 2007.

Table 1. Mean values $(n=15)$ and standard deviation $(\mathrm{SD})$ of the physical and chemical variables of the water recorded in the sampling months in Cachoeira Dourada reservoir of GO/MG.

\begin{tabular}{lccc}
\hline \multicolumn{1}{c}{ Variables } & $\begin{array}{c}\text { December 2006 } \\
\mathbf{n}=\mathbf{1 5}\end{array}$ & $\begin{array}{c}\text { May 2007 } \\
\mathbf{n}=\mathbf{1 5}\end{array}$ & $\begin{array}{c}\text { November 2007 } \\
\mathbf{n}=\mathbf{1 5}\end{array}$ \\
\hline Water temperature $\left({ }^{\circ} \mathrm{C}\right)$ & $25.58(\mathrm{SD}=0.18)$ & $25.78(\mathrm{SD}=0.25)$ & $26.23(\mathrm{SD}=0.44)$ \\
& $(25.9 \pm 25.3)$ & $(26.2-25.4)$ & $(28.08-25.71)$ \\
Electrical conductivity & $0.042(\mathrm{SD}=0.057)$ & $0.027(\mathrm{SD}=0.05)$ & $0.030(\mathrm{SD}=0.001)$ \\
$(\mu \mathrm{S} \mathrm{cm} / \mathrm{L})$ & $(0.29 \pm 0.028)$ & $(0.03-0.016)$ & $(0.031-0.016)$ \\
$\mathrm{OD}\left(\mathrm{mg} . \mathrm{L}^{-1}\right)$ & $5.52(\mathrm{SD}=0.95)$ & $6.62(\mathrm{SD}=1.76)$ & $7.34(\mathrm{SD}=0.95)$ \\
& $(6.68-5.19)$ & $(9.8-4.0)$ & $(11.78-6.32)$ \\
$\mathrm{pH}$ & $4.96(\mathrm{SD}=0.56)$ & $7.06(\mathrm{SD}=0.82)$ & $7.07(\mathrm{SD}=0.08)$ \\
& $(4.1-5.83)$ & $(8-5.36)$ & $(7.31-6.94)$ \\
Euphotic zone & $2.16(\mathrm{SD}=1.33)$ & $1.23(\mathrm{SD}=2.89)$ & $11.79(\mathrm{SD}=3.08)$ \\
& $(3.9-0.6)$ & $(12.3-6.75)$ & $(3-17.85)$ \\
Ammonia $\left(\mu \mathrm{gg} \cdot \mathrm{L}^{-1}\right)$ & $6.52(\mathrm{SD}=2.89)$ & $0.63(\mathrm{SD}=0.53)$ & $2.83(\mathrm{SD}=1.35)$ \\
& $(10.0-0.0)$ & $(1.47-0.0)$ & $(5.0-1.46)$ \\
Nitrate $\left(\mu \mathrm{g} . \mathrm{L}^{-1}\right)$ & $15.11(\mathrm{SD}=1.67)$ & $7.69(\mathrm{SD}=0.33)$ & $8.37(\mathrm{SD}=0.49)$ \\
& $(18.85-13.65)$ & $(8.29-7.28)$ & $(8.94-7.46)$ \\
Nitrite $\left(\mu \mathrm{g} . \mathrm{L}^{-1}\right)$ & $0.13(\mathrm{SD}=.10)$ & $0.26(\mathrm{SD}=0.23)$ & $0.16(\mathrm{SD}=0.013)$ \\
& $(0.30-0.03)$ & $(0.29-0.21)$ & $(0.18-0.14)$ \\
Ntotal $\left(\mu \mathrm{g} . \mathrm{L}^{-1}\right)$ & $640.74(\mathrm{SD}=134.65)$ & $50.92(\mathrm{SD}=8.25)$ & $1003.70(\mathrm{SD}=134.82)$ \\
& $(766.67-433.34)$ & $(61.66-40.0)$ & $(1100.0-833.34)$ \\
Pdissol $\left(\mu \mathrm{gg} . \mathrm{L}^{-1}\right)$ & $(0.14-0.0)$ & $0.11(\mathrm{SD}=0.13)$ & $0.30(\mathrm{SD}=0.007)$ \\
& $(\mathrm{SD}=0.051)$ & $(0.47-0.06)$ & $(0.32-.029)$ \\
Ptotal $\left(\mu \mathrm{g} . \mathrm{L}^{-1}\right)$ & $0.47(\mathrm{SD}=0.24)$ & $0.35(\mathrm{SD}=0.19)$ & $0.062(\mathrm{SD}=0.021)$ \\
& $(0.98-0.19)$ & $(0.78-0.21)$ & $(0.1-0.05)$ \\
\hline
\end{tabular}

belonging to nanophytoplankton (75\%) with higher records in the dry period - May 2007 (100\%).

The analysis of the spatial distribution of phytoplankton revealed the occurrence of 64 taxa at sampling point $1 ; 51$ at point 2;62 at point $3 ; 57$ at point 4 and 65 at point 5 . A higher number of taxa occurred at points 1 and 5 when compared with the other sampling points. Cyanophyceae constituted the group with the highest richness of taxa.

With respect to density, the highest values were also recorded at point 5 (960 ind. $\mathrm{mL}^{-1}$ ) and point 1 (602 ind. $\mathrm{mL}^{-1}$ ). Both points showed an increase in density starting from the first sampling campaign in December 2006 up 
Abundance (\%) of phytoplankton classes/Dec. de 2006

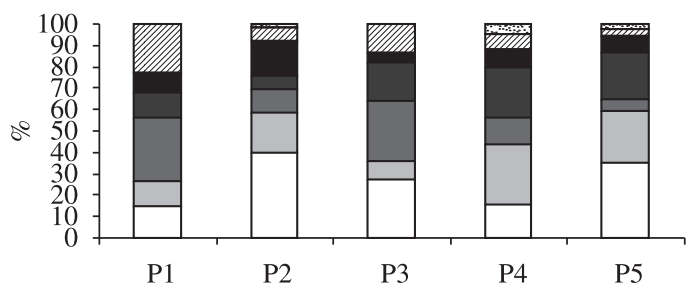

$\square$ Cyanophyceae $\square$ Euglenophyceae $\square$ Cryptophyceae - Bacillariophyceae - Chrysophyceae $\square$ Chlorophyceae Z Zygnematophyceae

Abundance (\%) of phytoplankton classes/May de 2007

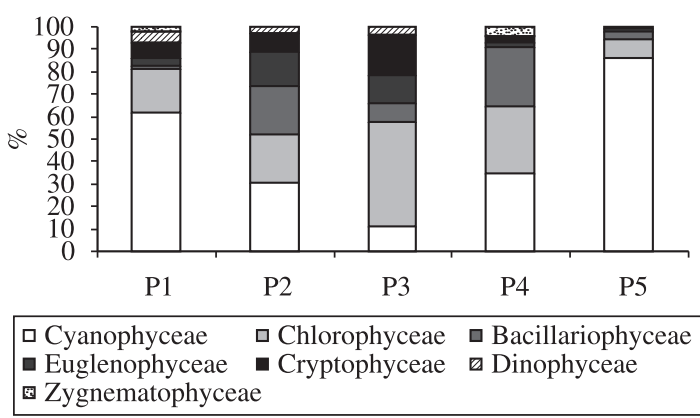

Abundance (\%) of phytoplankton classes/nov. 2007

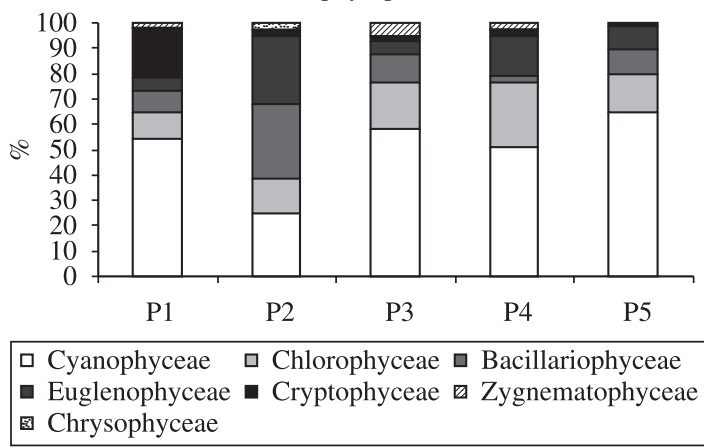

Figure 3. Relative density (\%) of the phytoplankton taxa grouped in the different taxonomic classes recorded at the five points distributed along the Cachoeira Dourada reservoir, GO/MG, in December 2006, May 2007 and November 2007.

to November 2007 (spring), showing evidence of the occurrence of interannual variability. A differentiated behavior was observed at point 2, which corresponds to the most lacustrine stretch closest to the dam. The lowest density in this stretch was recorded during the dry period (May 2007) and the highest in spring (November 2007).

Phytoplankton density was also higher in spring in the central part of the reservoir, corresponding to sampling points 3 and 4 .

A well marked seasonal variation in the composition of the phytoplankton groups was found at point 1 . In the rainy period (December 2006), Cryptophyceae (51 ind. $\mathrm{mL}^{-1}$ ) occurred in higher density, followed by Chlorophyceae (38 ind. $\mathrm{mL}^{-1}$ ) and Cyanophyceae (25 ind. $\left.\mathrm{mL}^{-1}\right)$. A predominance of Cyanophyceae occurred in the dry period (May 2007) and in spring (November 2007), with Cryptophyceae reappearing as the second most abundant group (Figure 3).

Point 2 was represented by a predominance of Cyanophyceae in the rainy period (December 2006) and in the dry period (May 2007), and by Bacillariophyceae and Euglenophyceae in November (spring) (Figure 3).

At point 3, Cyanophyceae ( 24 ind. $\mathrm{mL}^{-1}$ ) occurred in densities very similar to those of Cryptophyceae (25 ind. $\mathrm{mL}^{-1}$ ) in the rainy period (December 2006), representing $55.06 \%$ of the total density in the period under study. Chlorophyceae were predominant in the dry period and Cyanophyceae in spring (Figure 3).

Point 4 showed a predominance of Euglenophyceae and Bacillariophyceae in the rainy period, while Cyanophyceae, Chlorophyceae and Bacillariophyceae predominated in the dry period (May 2007) and Cyanophyceae in spring (November 2007), similarly to what was observed at points 1, 5 and 3 (Figure 3). Point 5 showed a predominance of Cyanophyceae, Euglenophyceae and Bacillariophyceae in the rainy period, while Cyanophyceae predominated in the dry period and in spring (Figure 3).

In general, it was found that the predominance of Cyanophyceae at the sampling points of this study showed a distinct seasonality. Moreover, when Cyanophyceae were not predominant, they were substituted by representatives of the classes Cryptophyceae, Chlorophyceae, Euglenophyceae and Bacillariophyceae.

There was no predominance of taxa (genera or species) at any of the sampling points. The representativeness of the species according to the criteria of Lobo and Leighton (1986) was at the level of abundant species, without reaching the criterion of dominant. The same classification indicated that, with respect to the dominance of higher taxonomic categories, there was group dominance, with Cyanophyceae predominating in the dry period (May 2007) and in spring (November 2007).

The most abundant phytoplankton taxa were grouped in 12 functional groups (FG), according to Reynolds' functional-group classification (1997 and 2002). Among these groups, $41.66 \%$ are common to mesotrophic environments (M, H2, W2, N and X2) and 48\% are found in nutrientrich environments ( $\mathrm{K}, \mathrm{S} 1, \mathrm{D}$, and $\mathrm{J})$, as indicated in the classification presented in Table 3.

Variations in the equitability index were low, with the lowest value of this index (0.7) obtained for the phytoplankton community at point 5 in the dry period, and the highest value (0.97) at point 4 in November 2007 in spring.

The fluctuations in richness and equitability were reflected directly in the variation in diversity at the various sampling sites. Higher indices were obtained at points 3 and 4 in November (beginning of the rainy season), with indices of 3.9 bits.ind $^{-1}$ and 4.1 bits.ind $^{-1}$, respectively. The lowest diversity (2.7) was obtained at point 5 in May. 
Table 2. List of taxa recorded in Cachoeira Dourada reservoir, GO/MG, with their respective classification regarding the occurrence frequency $(\mathrm{F})$ (where: $\mathrm{C}=$ constant, $*=$ frequent and $\mathrm{R}=$ rare) and $\mathrm{Ta}=$ average size $(\mu \mathrm{m})$ of species in December $2006(n=15)$, May $2007(n=15)$ and November $2007(n=15)$.

\begin{tabular}{|c|c|c|c|c|c|c|c|}
\hline Taxa & \multirow{2}{*}{$\%$} & \multirow{2}{*}{ Ta } & \multirow{2}{*}{ Clas } & Taxa & \multirow{2}{*}{$\%$} & \multirow{2}{*}{ Ta } & \multirow{2}{*}{ Clas } \\
\hline Cyanophyceae & & & & Bacillariophyceae & & & \\
\hline Anabaena sp. & 26.66 & 3,8 & + & $\begin{array}{l}\text { Aulacoseira ambigua } \\
\text { (Grunow) Simonsen }\end{array}$ & 20 & 23,0 & $\mathrm{R}$ \\
\hline $\begin{array}{l}\text { Aphanocapsa cf. koordersii } \\
\text { (Ström).Komarek }\end{array}$ & 6.66 & 1,5 & $\mathrm{R}$ & $\begin{array}{l}\text { Aulacoseira ambigua var. } \\
\text { spiralis (Muller) Simon }\end{array}$ & 6.66 & 25,0 & $\mathrm{R}$ \\
\hline Aphanocapsa sp. & 53,33 & 6,2 & $*$ & $\begin{array}{l}\text { Aulacoseira granulata } \\
\text { (Ehrenberg) Simonsen. }\end{array}$ & 80 & 21,5 & $\mathrm{C}$ \\
\hline Aphanothece sp. & 80 & 4,2 & $\mathrm{C}$ & Cyclotella sp. & 33.33 & 6,3 & + \\
\hline Células livres de Microcysis sp. & 66.66 & 4 & $*$ & Cymatopleura sp. & 6.66 & 50,0 & $\mathrm{R}$ \\
\hline $\begin{array}{l}\text { Chroococcus cf. minutus (Kützing) } \\
\text { Nägeli }\end{array}$ & 26.66 & 4,3 & $\mathrm{C}$ & Cymbella sp. & 60 & 30 & $*$ \\
\hline $\begin{array}{l}\text { Chroococcus cf. minimus } \\
\text { (Kützing.) Lemmermann. }\end{array}$ & 53.33 & 4,0 & $*$ & Diploneis sp. & 6.66 & 32,2 & $\mathrm{R}$ \\
\hline \multirow[t]{2}{*}{ Coelomoron sp. } & 13.33 & 3,0 & $\mathrm{R}$ & Eunotia sp. & 33.33 & 18,2 & + \\
\hline & & & & Fragilaria sp. & 20 & 44,3 & $\mathrm{R}$ \\
\hline $\begin{array}{l}\text { Geitlerinema unigranulatum } \\
\text { (Singh) Komarek. \& Azevedo }\end{array}$ & 73.33 & 4,5 & $*$ & Fragillaria sp.1 & 53.33 & 44,6 & $*$ \\
\hline Gomphosphaeria sp. & 13,33 & 3,4 & $\mathrm{R}$ & Fragillaria sp.2 & 6.66 & 45 & $\mathrm{R}$ \\
\hline Limnothrix sp. & 20 & 6,2 & $\mathrm{R}$ & Gomphonema sp. & 33.33 & 60 & + \\
\hline Lyngbya sp. & 6.66 & 4,1 & $\mathrm{R}$ & Gyrosigma sp. & 13.33 & 30,0 & $\mathrm{R}$ \\
\hline $\begin{array}{l}\text { Mastigocladus laminosus Nach } \\
\text { Sidler }\end{array}$ & 33,33 & 42,0 & + & Navicula sp. & 80 & 32,1 & $\mathrm{C}$ \\
\hline Merismopedia glauca Kützing & 6.66 & 3,1 & $\mathrm{R}$ & Nitzschia sp. & 13.33 & 130,15 & $\mathrm{R}$ \\
\hline $\begin{array}{l}\text { Microcystis aeruginosa (Kützing) } \\
\text { Kützing. }\end{array}$ & 33,33 & 2,4 & + & Pinnularia sp. & 33.33 & 42,8 & + \\
\hline Microcystis panniformis Komárek & 40 & 3,0 & + & Surirella sp. & 53.33 & 175,5 & $*$ \\
\hline Microcystis sp. & 13.33 & 4,0 & $\mathrm{R}$ & Tabellaria sp. & 6.66 & 100,0 & $\mathrm{R}$ \\
\hline $\begin{array}{l}\text { Oscillatoria cf. proboscídea } \\
\text { Gomont }\end{array}$ & 33,33 & 5,0 & + & Euglenophyceae & & & \\
\hline Oscillatoria sp. & 33.33 & 4,9 & + & Euglena sp. & 13.33 & 45,1 & $\mathrm{R}$ \\
\hline Phormidium sp.1 & 20 & 3,0 & $\mathrm{R}$ & $\begin{array}{l}\text { Trachelomonas cf. verrucosa } \\
\text { Stokes }\end{array}$ & 6.66 & 11,2 & $\mathrm{R}$ \\
\hline Phormidium sp. 2 & 26.66 & 3,0 & + & Trachelomonas sp. & 73.33 & 26,4 & $*$ \\
\hline Phormidium sp.3 & 6.66 & 3,0 & $\mathrm{R}$ & $\begin{array}{l}\text { Trachelomonas volvocina } \\
\text { Ehrenberg }\end{array}$ & 73.33 & 17,1 & $*$ \\
\hline Planktothrix sp. & 40 & 5,0 & + & Chrysophyceae & & & \\
\hline $\begin{array}{l}\text { Pseudanabaena } \\
\text { mucicola(Naumann et Hüber.- } \\
\text { Pelatozzit.) Schwabe. }\end{array}$ & 26.66 & 2,8 & + & $\begin{array}{l}\text { Dinobryon bavaricum } \\
\text { Coldwater Lake }\end{array}$ & 6.66 & 30 & $\mathrm{R}$ \\
\hline Pseudanabaena sp.1 & 73.33 & 5,9 & $*$ & Dinobryon sp. & 13.33 & 32 & $\mathrm{R}$ \\
\hline Pseudanabaena sp.2 & 40 & 7,0 & + & Mallomonas sp. & 33.33 & 16,7 & + \\
\hline Pseudanabaena sp.3 & 20 & 6,0 & $\mathrm{R}$ & Synura uvella Ehr. & 20 & 30,0 & $\mathrm{R}$ \\
\hline Spirulina sp. & 13.33 & 63,0 & $\mathrm{R}$ & Cryptophyceae & & & \\
\hline Westiella sp. & 6.66 & 9,5 & $\mathrm{R}$ & Cryptomonas sp. & 20 & 19,9 & $\mathrm{R}$ \\
\hline Wolskyella sp. & 13.33 & 20,0 & $\mathrm{R}$ & & & & \\
\hline
\end{tabular}


Table 2. Continued...

\begin{tabular}{|c|c|c|c|c|c|c|c|}
\hline Taxa & \multirow{2}{*}{$\%$} & \multirow{2}{*}{ Ta } & \multirow{2}{*}{ Clas } & Taxa & \multirow{2}{*}{$\%$} & \multirow{2}{*}{ Ta } & \multirow{2}{*}{ Clas } \\
\hline Chlorophyceae & & & & Zygnematophyceae & & & \\
\hline $\begin{array}{l}\text { Ankistrodesmus falcatus (Corda) } \\
\text { Ralfs }\end{array}$ & 20 & 44,4 & $\mathrm{R}$ & $\begin{array}{l}\text { Actinotaenium globosum } \\
\text { (Bulnheim) Krug Gerl }\end{array}$ & 6.66 & 29,2 & $\mathrm{R}$ \\
\hline Ankistrodesmus sp. & 6.66 & 47,8 & $\mathrm{R}$ & Closterium sp. & 26.66 & 62,3 & + \\
\hline Botryococcus sp. & 33.33 & 9,7 & + & $\begin{array}{l}\text { Cosmarium cf. decussiferum } \\
\text { Croasdale }\end{array}$ & 20 & 18 & $\mathrm{R}$ \\
\hline Chlamydomonas sp. & 86,66 & 17,1 & $\mathrm{C}$ & $\begin{array}{l}\text { Cosmarium cf. quadrum } \\
\text { Lundell }\end{array}$ & 13.33 & 52 & $\mathrm{R}$ \\
\hline Coelastrum microporum Nägeli & 13.33 & 11,2 & $\mathrm{R}$ & Cosmarium sp.1 & 33.33 & 62,5 & + \\
\hline $\begin{array}{l}\text { Coelastrum reticulatum } \\
\text { (P.A.Dangeard) Senn }\end{array}$ & 100 & 5,7 & $\mathrm{C}$ & $\begin{array}{l}\text { Desmidium cf. cylindricum } \\
\text { Greville }\end{array}$ & 20 & 33,5 & $\mathrm{R}$ \\
\hline $\begin{array}{l}\text { Dictyosphaerium pulchellum } \\
\text { Wood. }\end{array}$ & 40 & 5,8 & + & Desmidium sp. & 20 & 13,6 & + \\
\hline Dimorphococcus lunatus A. Braun & 6.66 & 7,6 & $\mathrm{R}$ & $\begin{array}{l}\text { Hyaloteca dissiliens (Smith) } \\
\text { Brebisson }\end{array}$ & 26.66 & 20,0 & + \\
\hline Elakatothrix cf. gelatinosa Wille & 33.33 & 15,6 & + & Hyaloteca sp. & 20 & 25,0 & $\mathrm{R}$ \\
\hline $\begin{array}{l}\text { Eutetramorus fottii (Hindák.) } \\
\text { Komárek. }\end{array}$ & 93.33 & 7,5 & $\mathrm{C}$ & Mougeotia sp.1 & 60 & 32,6 & $*$ \\
\hline Golenkiniospsis sp. & 6.66 & 8,3 & $\mathrm{R}$ & Mougeotia sp.2 & 33.33 & 30,0 & + \\
\hline $\begin{array}{l}\text { Kirchneriella cf. lunaris (Kirchner) } \\
\text { Möebius }\end{array}$ & 20 & 18,8 & $\mathrm{R}$ & Mougeotia sp 3 & 20 & 35 & $\mathrm{R}$ \\
\hline $\begin{array}{l}\text { Kirchneriella obesa (West. West) } \\
\text { Schmidle }\end{array}$ & 6.66 & 7,5 & $\mathrm{R}$ & $\begin{array}{l}\text { Sphaerozosma laeve } \\
\text { (Nordsted) Thomasson }\end{array}$ & 20 & 18,5 & $\mathrm{R}$ \\
\hline Micractinium sp. & 6.66 & 4,5 & $\mathrm{R}$ & Sphaerozosma sp. & 26.66 & 23,4 & + \\
\hline $\begin{array}{l}\text { Monoraphidium cf. griffthii(M.J. } \\
\text { Berkeley.) Komarkova.-Legn. }\end{array}$ & 13.33 & 36,1 & $\mathrm{R}$ & $\begin{array}{l}\text { Spondilosium cf. panduriforme } \\
\text { (Weste. \& G. S. West). Teiling }\end{array}$ & 6.66 & 39,0 & $\mathrm{R}$ \\
\hline $\begin{array}{l}\text { Monoraphidium circinale } \\
\text { (Nygaard) Nygaard. }\end{array}$ & 6.66 & 10,0 & $\mathrm{R}$ & Staurastrum laeve Ralfs & 6.66 & 20,0 & $\mathrm{R}$ \\
\hline Nephrocytium sp. & 26.66 & 13,5 & + & $\begin{array}{l}\text { Staurastrum leptocladum } \\
\text { Nordstedt }\end{array}$ & 46.66 & 40,5 & + \\
\hline Oocystis sp. & 20 & 8,8 & $\mathrm{R}$ & $\begin{array}{l}\text { Staurastrum leptocladum var. } \\
\text { cornutum Nordstedt }\end{array}$ & 20 & 60,0 & $\mathrm{R}$ \\
\hline $\begin{array}{l}\text { Scenedesmus cf. ecornis } \\
\text { (Ehrenberg) Chodat Nano }\end{array}$ & 13.33 & 20,0 & $\mathrm{R}$ & $\begin{array}{l}\text { Staurastrum margaritaceum } \\
\text { (Ehrenberg.) Ralfs }\end{array}$ & 6.66 & 22,2 & $\mathrm{R}$ \\
\hline Scenedesmus opoliensis Richter & 13.33 & 12,8 & $\mathrm{R}$ & $\begin{array}{l}\text { Staurastrum muticum (Bréb.) } \\
\text { Ralfs }\end{array}$ & 6.66 & 45,9 & $\mathrm{R}$ \\
\hline Scenedesmus sp. & 20 & 17,3 & $\mathrm{R}$ & Staurastrum rotula Nordstedt & 6.66 & 37,1 & $\mathrm{R}$ \\
\hline Schroederia sp & 6.66 & 85,5 & $\mathrm{R}$ & Staurastrum sp. & 26.66 & 32,4 & + \\
\hline Sphaerocystis sp. & 80 & 20,0 & $\mathrm{C}$ & $\begin{array}{l}\text { Staurodesmus cf. triangularis } \\
\text { (Lagerheim.) Teiling }\end{array}$ & 6.66 & 20,0 & $\mathrm{R}$ \\
\hline Volvox sp. & 26.66 & 5,0 & + & Staurodesmus sp. & 26.66 & 18,8 & + \\
\hline Dinophyceae & & & & Tetmemorus sp. & 6.66 & 20,4 & $\mathrm{R}$ \\
\hline \multirow[t]{3}{*}{ Peridinium sp. } & 46.66 & 23,4 & + & Xanthophyceae & & & \\
\hline & & & & $\begin{array}{l}\text { Isthmochloron lobulatum } \\
\text { (Nägeli.) Skuja }\end{array}$ & 13.33 & 10,0 & $\mathrm{R}$ \\
\hline & & & & Tetraplektron sp. & 6.66 & 18,0 & $\mathrm{R}$ \\
\hline
\end{tabular}


Table 3. Main Functional Groups (FG) and taxa with highest relative contribution (\%) to the density of the phytoplankton community of Cachoeira Dourada reservoir, GO/MG, in December 2006, May 2007 and November 2007.

\begin{tabular}{|c|c|c|}
\hline FG & $\begin{array}{l}\text { Characteristics of the Functional Groups } \\
\text { (Reynolds, 1997; Reynolds et al., 2002). }\end{array}$ & $\begin{array}{l}\text { Main taxa representative of each } \\
\text { functional group (FG) }\end{array}$ \\
\hline $\mathrm{K}$ & $\begin{array}{l}\text { Occur in nutrient-rich epilimnion; sensitive to deep mixing and } \\
\text { tolerant to high light intensity. }\end{array}$ & $\begin{array}{l}\text { Aphanocapsa sp., and } \\
\text { Aphanothece } \text { sp. }\end{array}$ \\
\hline $\mathrm{S} 1$ & $\begin{array}{l}\text { Occur in turbid and mixed waters; tolerant to light deficiency; } \\
\text { sensitive to high flows. }\end{array}$ & $\begin{array}{c}\text { Pseudanabaenamucicola; } \\
\text { Pseudanabaena sp., e Limnothrix sp. }\end{array}$ \\
\hline M & $\begin{array}{l}\text { Occur in mesotrophic environments with mixed water column; } \\
\text { tolerant to strong sunlight; sensitive to flooding and low } \\
\text { transparency. }\end{array}$ & Microcystis sp. \\
\hline $\mathrm{H} 2$ & $\begin{array}{l}\text { Nitrogen-fixing Nostocales in large mesotrophic lakes; tolerant to } \\
\text { low nitrogen concentrations, mixing and low light availability. }\end{array}$ & Anabaena sp. \\
\hline W2 & Occur in mesotrophic lakes & $\begin{array}{l}\text { Trachelomonas volvocina and } \\
\text { Trachelomonas sp. }\end{array}$ \\
\hline $\mathrm{J}$ & $\begin{array}{l}\text { Occur in rivers and shallow, nutrient-rich lakes; sensitive to } \\
\text { sedimentation in aphotic layers. }\end{array}$ & Coelastrum reticulatum \\
\hline $\mathrm{N}$ & $\begin{array}{l}\text { Occur in mesotrophic epilimnion; tolerant to nutrient deficiency; } \\
\text { sensitive to stratification and high } \mathrm{pH} \text {. }\end{array}$ & Pinullaria sp. \\
\hline $\mathrm{D}$ & $\begin{array}{l}\text { Occur in shallow, turbid and eutrophic environments, including } \\
\text { rivers; tolerant to high flows; sensitive to nutrient depletion. }\end{array}$ & Cyclotella sp. \\
\hline $\mathrm{X} 2$ & $\begin{array}{l}\text { Occur in lakes with mixed water column, transparent and } \\
\text { mesotrophic; tolerant to stratification. }\end{array}$ & Chlamydomonas sp. \\
\hline $\mathrm{P}$ & $\begin{array}{l}\text { Occur in meroplankton, tolerant to constant wind turbulence; } \\
\text { sensitive to stratification. The include periphytic diatoms with } \\
\text { occasional occurrence of lake plankton. }\end{array}$ & Aulocoseira granulata \\
\hline $\mathrm{E}$ & $\begin{array}{l}\text { Usually occur in small oligotrophic or mesotrophic lakes; tolerant } \\
\text { to low nutrient concentrations (mixotrophy). }\end{array}$ & Dinobryon sp. \\
\hline $\mathrm{Y}$ & $\begin{array}{l}\text { Usually occur in small nutrient-rich lakes; tolerant to light } \\
\text { deficiency; sensitive to nutrient deficiency and to herbivory. }\end{array}$ & Cryptomonas sp. \\
\hline
\end{tabular}

Canonical correspondence analysis (CCA) was used to correlate the abundant species (descriptors) with the physical and chemical variables recorded in the period of this study. Axis 1 of the CCA (F1) provided $88.53 \%$ of explanation of the variability and axis 2 (F2) $9.56 \%$, while the two axes together presented a total explainability of $98.09 \%$ (Figure 4). The results of the Monte Carlo test indicated that the variables of dissolved phosphorus (0.001). TIN (0.001) and Secchi (0.033) were significantly correlated with the community.

The analysis revealed three large groups classified according to the dynamics of the variables. The first group was related to the elements of dissolved phosphorus and water column transparency (Secchi), which were correlated with Cyanophyceae as Limnothrix sp. (sp.10), Chroococcus minimus (sp.12), Aphanothece sp. (sp.15) and Aphanocapsa sp. (sp.2), Euglenophyceae as Trachelomonas sp. (sp.18), Chlorophyceae as Coelastrum reticulatum (sp.8) and Scenedesmus sp. (sp.20), and Bacillariophyceae as Navicula sp. (sp.16) and Cyclotella sp. (sp.9), all of which were numerically more significant in November (spring) (Figure 4).
The second group was represented by the temperature factor, which was correlated with the following taxa: Microcystis sp. (free cells) (sp.3), Microcystis sp. (sp.4), Anabaena sp. (sp.1) and Pseudanabaena muscicola (sp.7), all belonging to the class Cyanophyceae, with higher representativeness in the dry period (May 2007) at points 1, 3, 4 and 5 (Figure 4).

The third group consisted of phytoflagellates, comprising the taxa Trachelomonas volvocina (sp.19), Cryptomonas sp. (sp.22) and Chlamydomonas sp. (sp.17). The increased density of these species was correlated with the increase in the concentrations of nitrogen compounds that occurred in December (summer/rainy) (Figure 4).

The taxon Dinobryon sp. (sp.24) (Chrysophyceae) occurred only in December. It is believed that the increase in inorganic dissolved nitrogen, which occurred in this period, may have contributed to the development of this alga. In addition to the aforementioned environmental factors, aspects such as cell morphology and locomotor structures such as sheaths or flagella were found to be determining factors in the selection of the group of species (Figure 4). 


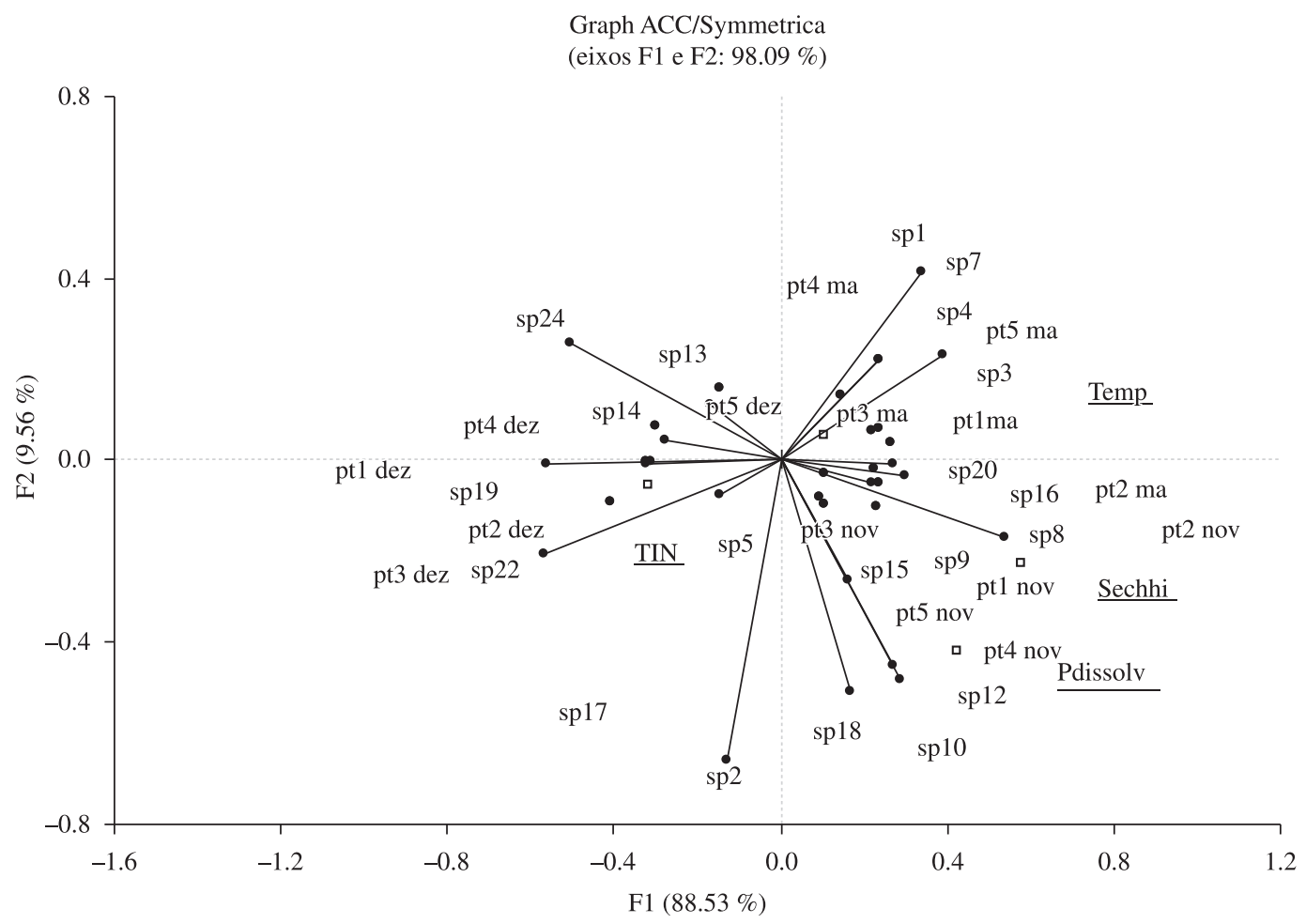

Figure 4. Canonical Component Analysis (CCA) at the different points in Cachoeira Dourada reservoir, correlating chemical, physical and biological variables. TIN = Total inorganic nitrogen; $\mathrm{P}$ dissov $=$ dissolved phosphorus; Temp = temperature; and Secchi = water transparency. The sampling points are identified as pt $1=$ point 1 and so on successively; months appear as Dec $=$ December, May $=$ May and Nov $=$ November. Taxa are identified as sp. $1=$ Anabaena sp., sp. $2=$ Aphanocapsa sp., sp. 3 = free cells of Microcystis sp., sp.4 = Microcystis sp., sp.5 = Pseudanabaena sp. 1 , sp.7 = Pseudanabaena mucicola, sp. $8=$ Coelastrum reticulatum, sp. $9=$ Cyclotella sp., sp. $10=$ Limnothrix sp., sp. $12=$ Chroococcus cf. minimus, sp. $13=$ Aulacoseira granulata, sp.14 = Pinnularia sp., sp.15 = Aphanothece sp., sp16 = Navicula sp., sp. $17=$ Chlamydomonas sp., sp.18 = Trachelomonas sp., sp.19 = Trachelomonas volvocina, sp.20 = Scenedesmus sp., sp.22 = Cryptomonas sp. and sp.24 = Dinobryon sp.

\section{Discussion}

The Cachoeira Dourada reservoir stands out from the others in the cascade of reservoirs of the Paranaíba River for its narrow elongated configuration, relatively low depth and short residence time. It is the only reservoir in this basin that operates on "a trickle of water", i.e., without being a reservoir in the strictest sense of the word.

Short residence times cause loss of biomass by hydraulic washout and mechanical shock in phytoplankton cells (Kimmel et al., 1990; Straskraba et al., 1993). In the Cachoeira Dourada reservoir, the average water residence time of 3 days, allied to the low light penetration (low water transparency) in the rainy period, may have been limiting factors for the development of phytoplankton and the resulting lower density observed in this period. Pivato et al. (2006) found a similar situation in the Corumbá reservoir. The author points out that the short water residence time, which was only 10 days in April, allied to the low availability of light, acted negatively on the phytoplankton assemblages, contributing to the low density and biomass observed in the period.
Henry et al. (1985) state that an appreciable phytoplankton development requires retention times of at least 2 to 3 weeks to allow for significant growths of phytoplankton organisms. In their study of reservoirs, Zalewski et al. (2000) concluded that retention time is one of the best tools for the control of toxic algal blooms.

The average density of the phytoplankton community in the Cachoeira Dourada reservoir was lower than that recorded by Pinto-Coelho (2004) in the São Simão reservoir and by Figueiredo (2007) in the Manso reservoir. However, in 2008 and 2009, the average density of phytoplankton in the Uberabinha River (SUPRAM, 2010), belonging to the same hydrographic basin, was lower than that recorded in Cachoeira Dourada, which should be influenced, at least to some extent, by the different water residence times of these systems.

As for temporal variations, the density values were higher in spring, which is a period of low rainfall. As the rainy period advanced, the density of the phytoplankton community decreased in response to the increasing water flow. This pattern of temporal variation has been 
observed regularly in several reservoirs and lacustrine systems in southeastern Brazil (Nogueira, 2000; Souza and Fernandes, 2009).

In terms of richness, an increase was found in the number of taxa as the rains intensified. Cyanophyceae occurred with the highest number of taxa in the three periods studied. A relevant aspect is the fact that in this reservoir, unlike what was observed in the São Simão reservoir located in the same hydrographic basin (Pinto-Coelho, 2004), free-living cells of Microcystis are predominant rather than colonial cell forms. This may be explained by the fast-flowing current and high turbulence prevailing in Cachoeira Dourada.

Knowledge of the diversity, equitability and richness of phytoplankton communities is a very useful instrument for the characterization of an aquatic ecosystem. Estimates of diversity can be used as indicators of the situation of ecological systems (Magurram, 1988) serving as a measure of the stability of a community and its resistance to several types of disturbances (Barnese and Schelske, 1994).

The mean value of phytoplankton diversity in Cachoeira Dourada was 3.4 bits.ind $^{-1}$, with the highest value recorded in spring (4.11 bits.ind ${ }^{-1}$ ), probably due to the hydrological instability caused by the strong rains characteristic of the onset of the rainy season in tropical regions, which carry dissolved phosphorus from surrounding terrestrial areas. In a study of the Barra Bonita reservoir, Padisak et al. (2000), found values of up to 3.18 bits.ind $^{-1}$. Reservoirs with different characteristics from those of Cachoeira Dourada and with high residence times (Beyruth, 2000; Calijuri et al., 2002) may favor a state close to equilibrium, which is characterized by low plankton diversity and frequent cyanobacterial blooms.

As a group, Cyanophyceae predominated in the dry period but showed reduced density in spring with the onset of the rains, when they ceased to be dominant but still continued to show the highest numerical density. With the decline of cyanobacteria in the rainy period, there was an increase in the phytoflagellate species, which was favored by augmented allochthonous input of organic matter.

The first peak of cyanobacteria was dominated by Microcystis sp. and filamentous cyanobacteria (Pseudanabaena muscicola, Anabaena sp.) and the second peak by colonial cyanobacteria (Aphanocapsa sp. and Aphanothece sp.). The decline in the reservoir's water volume in the dry period and in spring seems to favor the prevalence and increase of the biomass of cyanobacterial species. Fonseca and Rodrigues (2005) found that oscillations of the water level in the floodplain of the upper Paraná River promoted by the rainfall regimes determined the seasonalness of limnological factors and explained the temporal variation of cyanobacteria.

The $\mathrm{pH}$ was higher when the algal density was greater, this augmented $\mathrm{pH}$ may have been a consequence of the increase in photosynthesis.

In the Cachoeira Dourada reservoir, Cyanophyceae were represented by the functional groups K, S1, M and $\mathrm{H}$. The M-associated cyanobacteria consisted essentially of Microcystis spp. with higher densities in the dry period. In this period, Microcystis sp. were found to coexist with filamentous species of the S1 (Pseudanabaena muscicola) and $\mathrm{H}$ (Anabaena spp.) groups. The $\mathrm{H}$ group species are nitrogen fixers, tolerating low concentrations of this element in water. These findings are contrary to those recorded by Huszar et al. (2000) in a reservoir not deficient in nitrogen, which showed a dominance of heterocytic cyanobacteria in northeastern Brazil. From the various sources of information in the literature and from the field observations of the present study, it can be inferred that the occurrence of these groups is never the result of only one factor acting alone.

Based on a canonical correspondence analysis (CCA), the species Microcystis sp., Pseudanabaena muscicola and Anabaena sp. were associated to the variable of temperature (dry period), which was on average $25.8{ }^{\circ} \mathrm{C}$. Jöhnk et al. (2008) compared the growth rate of populations of Microcystis, green algae and diatoms and found that at low temperatures (below $23{ }^{\circ} \mathrm{C}$ ), Microcystis presented a lower growth rate than the other algae. However, the growth rate of Microcystis showed a direct correlation with temperatures, i.e., higher growth with increased temperature and a higher optimal temperature (above $23{ }^{\circ} \mathrm{C}$ ) than that of green algae and diatoms. These findings demonstrate that Microcystis is a strong competitor at high temperatures, as are the other Cyanobacteria (Fernandes et al., 2009).

On the other hand, the colonial coccoid species of functional group K (Aphanothece spp. and Aphanocapsa spp.) present similar morphological traits (coccoidal colonies) and the same nutritional demand (Reynolds et al., 2002), which undoubtedly facilitates their coexistence in spring, associated with the availability of dissolved phosphorus (CCA) and higher water transparency. Species of the functional group $\mathrm{K}$, which commonly occur in shallow and enriched lakes, though sensitive to deep-mixing (Reynolds et al., 2002), presented constancy on the temporal scale (in the three periods analyzed). However, its density showed significant variability in spring with the onset of the first rains.

Pivato et al. (2000) attribute the distribution of Aphanothece sp. to the presence of their mucilaginous sheath, an important structure for their suspension in the water column in periods of turbulence, which probably favored the permanence of this taxon in the plankton of Cachoeira Dourada.

Chlorophyceae, which constituted the group with the second highest representativeness in the Cachoeira Dourada reservoir, are commonly recorded as the most important in terms of the number of plankton species in freshwater environments. They are favored by their high morphometric variability and their ability to develop in a variety of habitats (Train et al., 2006). Among the Chlorophyceae, Chlorococcales stand out because their representatives are common in any type of environment (Bicudo and Menezes, 2006; Fonseca et al., 2009) and they are also among the first to colonize the environment (Bicudo and Menezes, 2006). 
These algae were represented principally by small colonial species, with Coelastrum reticulatum standing out in spring (sampling point 5) and flagellates such as Chlamydomonas sp. (point 1 ) in the rainy period, when they were a common occurrence in the nanophytoplankton. In his limnological characterization of the hydropower plant of Ipueiras, Reis-Pereira (2002) points out the high contribution of Chlorophyceae to the phytoplankton community, with relative abundances varying from $34 \%$ to $74 \%$ of the total abundance. This group is also well represented in other Brazilian environments, indicating the good adaptation of these species to tropical eutrophic aquatic environments (Sant'Anna and Azevedo, 2000; Padisák et al., 2000).

In Cachoeira Dourada, the CCA analysis associated the taxon Coelastrum reticulatum to the variables of dissolved phosphorus and water transparency (spring). According to Reynolds et al. (2002), this species belongs to the functional group $\mathrm{J}$, and its occurrence is common in shallow enriched lakes. On the other hand, the taxon Chlamydomonas sp. was associated with nitrogen compounds (TIN), particularly ammonia. According to Reynolds et al. (2002), Chlamydomonas sp., belongs to functional group $\mathrm{X} 2$, which is characteristic of transparent and mesotrophic environments. These algae species have short life cycles and they are opportunists, reaching rapid growth rates when nutrient availability is adjusted (Happey-Wood, 1988), generally related with the process of eutrophication (Biggs, 1996).

Small diatoms (Cyclotella spp.) appeared as an abundant taxon in spring, coexisting with colonial cyanobacteria such as Aphanocapsa spp., Aphanothece spp. and chlorophytes such as Coelastrum reticulatum. Cyclotella sp. diatoms are grouped by Reynolds et al. (2002) in functional group $\mathrm{D}$, which is common in shallow well-mixed enriched lakes. In the Cachoeira Dourada reservoir, this group was correlated (CCA) with water transparency and dissolved phosphorus, with higher importance at points 3 and 4 , the central region of the reservoir, corroborating the finding of Reynolds et al. (2002), who associate the species to turbulent habitats with lotic influence.

The Euglenophyceae algae, abundant in the rainy period, were represented by Trachelomonas volvocina. The increment in the density of this taxon was correlated (CCA) with nitrogen compounds, especially ammonia. Probably, the input of organic matter resulting from the rains in December intensified the process of decomposition, increasing turbidity and reducing the $\mathrm{pH}$, thus creating favorable conditions that would undoubtedly benefit the growth of this species. The species Trachelomonas volvocina is classified by Reynolds et al. (2002) in functional group W2, occurring in mesotrophic lakes. Authors such as Alves-da-Silva and Bridi (2004) associate the class Euglenophyceae to environments rich in organic matter, which may have been the case in the Cachoeira Dourada reservoir, at least in stretches under the influence of organic effluents.
In a study of the phytoplankton community in a sport fishing pond in São Paulo, Matsuzaki et al. (2004) observed that Euglenophyceae were favored in environments of low transparency because they possess flagella, enabling them to move to layers with higher light intensity in the water column.

Cryptophyceae were represented in the Cachoeira Dourada reservoir by the taxon Cryptomonas sp., associated (CCA) with nitrogen compounds (TIN) and especially ammonia in the rainy period, when an average density of 51 ind. $\mathrm{L}^{-1}$ was recorded at point 1 and of 25 ind. $\mathrm{L}^{-1}$ at point 3 . These algae were more abundant in the rainy period (December 2006) in the central part of the reservoir. A similar situation was observed in the São Simão reservoir with phytoflagellate cryptophyte algae, mainly Cryptomonas erosa and $C$. brasiliensis, which were abundant in January 2002 (rainy period), particularly in the central portion close to the dam, where they reached densities exceeding 2000 ind. $\mathrm{mL}^{-1}$ (Pinto-Coelho, 2004).

In the Cachoeira Dourada reservoir, dinoflagellates represented by the taxon Peridinium sp. were not numerically significant and were classified as constant in the dry period (May), with records at all the collection points. Indications are that this taxon was favored by the conditions of higher availability of dissolved oxygen $\left(9.8 \mathrm{mg} . \mathrm{L}^{-1}\right)$ at point 1 . The decline of this element in the water caused the density of this taxon to diminish at the other sampling points.

The Zygnematophyceae class represented $22.9 \%$ of the species richness found in the plankton of the reservoir, but it occurred in low densities. These algae constitute a representative group of the periphyton, and are found mainly in environments of nutrient-poor acidic water with low electrical conductivity and high transparency (Felisberto and Rodrigues, 2005). In Cachoeira Dourada, a positive correlation was found between the Chlorophyceae (Scenedesmus sp.) density and water transparency. This correlation is consistent with the findings of Felisberto and Rodrigues (2005), Martins and Fernandes (2007), Cavati and Fernandes (2008) for lakes and reservoirs in southeastern Brazil.

A joint analysis of the abundant species indicated the process of substitution of species occurring in the phytoplankton community between the collection periods. There were signs that the species' morphological, morphometric, physical and nutritional traits were determining factors in the process of selection.

Therefore, phytoflagellates (Cryptomonas sp. and Trachelomonas volvocina) were abundant in summer (rainy), together with colonial cyanobacteria of the order Chroococcales (Aphanothece sp.), alternating to free-living cells of Microcystis sp., Anabaena spp., and Microcystis sp., coexisting, respectively, with small green colonial algae and flagellates in the dry period (Coelastrum reticulatum and Chlamydomonas sp.). In spring an abundance of colonial cyanobacteria (Aphanocapsa sp. and Aphanothece sp.) and green colonial algae of the order Chlorococcales (Coelastrum reticulatum) was observed coexisting with 
species such as Cyclotella spp., Cryptomonas sp., and Chroococcus minimus.

However, it should be noted that phytoplankton presented two density peaks, one in spring (November) and the other in the dry period (May). The increase of species in spring was associated with the first rains, which were responsible for a slight increase in phosphate compounds in the water. The rains facilitated the process of removal from the bottom of the reservoir, bringing nutrients essential to phytoplankton development to the surface. Another important factor is light availability, which remained high in the dry period and in spring. The occurrence of nitrogen-fixing cyanobacteria in the dry period was attributed to their ability to stock phosphorus and to tolerate environments poor in phosphorus compounds.

According to the functional group analysis, the phytoplankton community was represented by species typical of turbulent and enriched environments. The temporal variability of the chemical and hydrodynamic characteristic of the reservoir was reflected in the density of each group in the different periods. Some species such as Anabaena sp. and Microcystis sp. are indicators of eutrophicated environments and can be considered potentially toxic. However, it is important to point out that these species did not occur in high densities, suggesting that the current state of the Cachoeira Dourada reservoir, albeit not one of eutrophication according to the criteria adopted by the CONAMA resolution, shows a strong tendency for the establishment of this trophic state. The system's hydrodynamics seems to operate as a continual regenerator of habitat conditions, preventing the community from maturing and thus reaching a state of equilibrium (Sommer et al., 1993). This fact explains the lack of dominance and the low density of phytoplankton species recorded in the Cachoeira Dourada reservoir.

Another important factor was the predominance of $\mathrm{C}$ - strategist species that make up the nanophytoplankton, which were abundant throughout the period of this study. Despite the weak spatial pattern (among sampling points), hydrodynamics and seasonal variation were important in constituting the composition of the phytoplankton community. Notwithstanding the predominance of cyanobacteria, the reservoir presented the characteristics of an oligotrophic environment, albeit with a certain tendency for eutrophication. The absence of blooms and its moderate phytoplankton densities lead to the conclusion that the quality of the reservoir's water still remains within the limits established for its multiple uses.

\section{References}

Ameruca Public Health Association - APHA, 1995. Standard methods for examination of water and wasterwater. 19nd ed. Washington: APHA.

ALVES-DA-SILVA, SM. and BRIDI, FC., 2004. Euglenophyta in the Jacui Delta State Park, Rio Grande do Sul State, Southern Brazil 3. The genus Strombomonas Deflandre. Acta Botânica Brasilica, vol. 18, no. 3, p. 555-572.
BARNESE, LE. and SCHELSKE, CL., 1994. Effects of nitrogen, phosphorus and carbon enrichment on planktonic and periphytic algae in a sofwater, oligotrophic lake in Florida, U.S.A. Hydrobiologia, vol. 289, p. 199-214.

BEYRUTH, Z., 2000. Periodic disturbances, trophic gradient and phytoplankton characteristics related to cyanobacterial growth in Guarapiranga Reservoir, São Paulo State, Brazil. Hydrobiologia, vol. 424, no. 1/3, p. 51-65. http://dx.doi.org/10.1023/A:100394472634

BICUDO, CEM. and MENEZES, M., 2006. Gêneros de algas de águas continentais do Brasil: chave para identificação e descrições. 2nd ed. São Carlos: Rima.

BIGGS, BJF., 1996. Patterns in benthic algae of streams. In STEVENSON, RJ., BOTHWELL, ML. and LOWE, RL. (Ed.). Algal ecology: freshwater benthic ecossistems. San Diego: Academic Press. p. 31-56. vol. 2.

BORGES, PAF., TRAIN, S. and RODRIGUES, L., 2008. Spatial and temporal variation of phytoplankton in two subtropical Brazilian reservoirs. Hydrobiologia, vol. 607, no. 1, p. 63-74. http://dx.doi.org/10.1007/s10750-008-9367-3

BRASSAC, NM. and LUDWIG, TAV., 2003. Fragilariaceae (Bacillariophyceae) de rios da bacia do Iguaçu, Estado do Paraná, Brasil. Revista Brasileira de Botânica, vol. 26, no. 3, p. 311-318. http://dx.doi.org/10.1590/S0100-84042003000300004

-, 2005. Amphipleuraceae and Diploneidaceae (Bacillariophyceae) from Iguaçu River basin, PR, Brazil. Acta Botânica Brasilica, vol. 19, no. 2, p. 359-368. http://dx.doi.org/10.1590/S010233062005000200019

CABRAL, JBP., BECEGATO, VA. and SCOPEL, I., 2005. Uso de técnicas de geoprocessamento para mapear o potencial natural de erosão da chuva na bacia hidrográfica do reservatório de Cachoeira Dourada - GO/MG. Revista RA'E GA, no. 10, p. 107-116.

CALIJURI MC., DOS SANTOS, ACA. and JATI, S., 2002. The impacts caused by dam construction, including public health problems due to environmental deterioration, are mainly related to reservoir's size, volume and retention time, its geographic location, among other factors (Tundisi, Matsumura-Tundisi and Rocha, 2002). Plankton Research, vol. 24, no.7, p. 617-634.

CAVATI, B. and FERNANDES, VOF., 2008. Algas perifíticas em dois ambientes do baixo rio Doce (lagoa Juparanã e rio Pequeno - Linhares, Estado do Espírito Santo, Brasil): variação espacial e temporal. Acta Scientiarum. Biological Sciences, vol. 30, no. 4, p. 439-448. http://dx.doi.org/10.4025/actascibiolsci.v30i4.535

CHELLAPPA, NT., CÂMARA, FRA. and ROCHA, O., 2009. Phytoplankton community: indicator of water quality in the Armando Ribeiro Gonçalves Reservoir and Pataxó Channel, Rio Grande do Norte, Brazil. Brazilian Journal of Biology, vol. 69, no. 2, p. 241-251. http://dx.doi.org/10.1590/S1519-69842009000200003

COSTA, M., BOSCA, C. and DAUTA, A., 1991. Use of algae for monitoring rivers in France. In WHITTON, BA., ROTT, E. and FRIEDRICH, G. (Eds.). Use of algae for monitoring rivers. Innsbruck: Institut fur Botanik, Universitat Innsbruck. p. 75 - 88.

CROSSETTI, LO. and BICUDO, CEM., 2005. Structural and functional phytoplankton responses to nutrient impoverishment in mesocosms placed in a shallow eutrophic reservoir (Garças Pond), São Paulo, Brazil. Hydrobiologia, vol. 541, p. 71-85.

DAJOZ, R., 1973. Ecologia geral. São Paulo: Editora Vozes Ltda/EDUSP. 472 p. 
EDLER, L., 1979. Recommendations for marine biological studies in the Baltic Sea, phytoplankton and chlorophyll. UNESCO, Working Group 11, Baltic Marine Biologists. 1979. 38 p.

ESTEVES, FA., 1998. Fundamentos de Limnologia. 2nd ed. Rio de Janeiro: Ed. Interciência, 602 p.

FELISBERTO, AS and RODRIGUES, L., 2005. Influência do gradiente longitudinal (rio-barragem) na similaridade das comunidades de desmídias perifíticas. Revista Brasileira de Botânica, São Paulo, vol. 28, no. 2, p. 241-254. http://dx.doi. org/10.1590/S0100-84042005000200005

FERNANDES, LF., WOSIACK, AC., PACHECO, CV., DOMINGUES, L. and LOPES, PD., 2005. Cianobactérias e cianotoxinas. In ANDREOLI, CV. and CARNEIRO, C (Eds.). Gestão integrada de mananciais de abastecimento eutrofizados. Curitiba: SANEPAR. p. 367-388

FERNANDES, VO., CAVATI, B., OLIVEIRA, LB and SOUZA, BDAS., 2009. Ecologia de cianobactérias: Fatores promotores e consequências das florações. Oecologia Brasileinsis, vol 13, no. 2, p. 247-258. http://dx.doi.org/10.4257/oeco.2009.1302.03

FIGUEIREDO, DM., 2007. Padrões limnológicos e do fitoplâncton nas fases de enchimento e de estabilização dos reservatórios do APM Manso e AHE Jauru (Estado de Mato Grosso). São Carlos: Universidade Federal de São Carlos. 285 p. Tese de Doutorado em Ecologia e Recursos Naturais.

FONSECA, IA. and RODRIGUES, L. 2005. Comunidades de algas perifíticas em distintos ambientes da planície de inundação do Alto rio Paraná. Acta Scientiarum Biological Sciences, vol. 27, no. 1, p. 21-28.

FONSECA, IA, SIQUEIRA, NS. and RODRIGUES, L., 2009. Algas perifíticas a montante e a jusante do local de instalação de tanques-rede em tributários do reservatório de Rosana, Estado do Paraná, Brasil. Acta Scientiarum Biological Sciences, vol. 31. no. 2, p. 135-141.

GEMELGO, MCP., MUCCI, JLN. and NAVAS-PEREIRA, D., 2009. Population dynamics: seasonal variation of phytoplankton functional groups in Brazilian reservoirs (Billings and Guarapiranga, São Paulo). Brazilian Journal of Biology, vol. 69. no. 4, p. 1001-1013.

HAPPEY-WOOD, VM., 1988. Ecology of freshwater planktonic green algae. In SANDGREEN, CD. (Ed.). Growth and reproductive strategies of freshwater phytoplankton. New York: Cambridge University Press. p. 175-226.

HENRY, R., HINO, K., GENTIL, JG. and TUNDISI, JG., 1985. Primary production and effects of enrichment with nitrate and phosphate on phytoplankton in the Barra Bonita Reservoir (State of São Paulo, Brazil). Hydrobiologia, vol 7, p. 561-573.

HUSZAR, VLM., SILVA, LHS, MARINHO, MM, DOMINGOS, P. and SANT 'ANNA CL., 2000. Cyanoprokaryote assemblages in eight productive tropical Brazilian waters. Hydrobiologia, vol. 424, p. 67-77. http://dx.doi.org/10.1023/A:1003996710416

HUSZAR, VLM., KRUK, C. and CARACO, N., 2003. Steadystate assemblages of phytoplankton in four temperate lakes (NE U.S.A.). Hydrobiologia, vol. 502, no.1/3, p. 97-109. http://dx.doi. org/10.1023/B:HYDR.0000004273.40488.0

JÖHNK, KD., HUISMAN, J., SHARPLES, J., SOMMEIJER, B., VISSER, PM. and STROOM, JM., 2008. Summer heatwaves promote blooms of harmful cyanobacteria. Global Change Biology, vol. 14 , no. 3, p. 495-512. http://dx.doi.org/10.1111/j.13652486.2007.01510.x
KIMMEL, BL., LIND, OT. and PAULSON, LJ., 1990. Reservoir primary production. In THORNTON, KW., KIMMEL, BL. and PAYNE, FE. (Eds.). Reservoir limnology: ecological perspectives. New York: John Wiley \& Sons, Interscience Publication. p. 133194. vol. 6

KOROLEFF, F., 1976. Determination of nutrients. In GRASHOFF, K. (Ed). Methods of seawater analysis. Verlag Chemie Weinhein. 117$181 \mathrm{p}$.

KRUK, C., MAZZEO, N., LACEROT, G. and REYNOLDS, CS., 2002. Classification schemes of phytoplankton: a local validation of a functional approach to the analysis of species temporal replacement. Jornal of Plankton Research, vol. 24. no. 9, p. 901-912. http://dx.doi.org/10.1093/plankt/24.9.901

LOBO, E., and LEIGHTON, G., 1986. Estructuras comunitarias de las fitocenosis planctónicas de los sistemas de desembocaduras de rios y esteros de la zona central de Chile. Revista de Biologia Marina y Oceanografía, Valparaíso, vol. 22, no.1, p.1-29.

LOPES, MRM., BICUDO., CEM. and FERRAGUT, MC., 2005. Short term spatial and temporal variation of phytoplankton in a shallow tropical oligotrophic reservoir, southeast Brasil. Hydrobiologia, vol. 542, p. 235-247. http://dx.doi.org/10.1007/ s10750-004-8332-z

MACKERETH, FYH., HERON, JR. and TAILING, JF., 1978. Water analysis: some revised methods for limnologists. Ambleside: Freshwater Biological Association:Scientific Publications, vol. 30 , p. 36.

MAGURRAM, AE., 1988. Ecological Diversity and its Measurement. Cambridge. $179 \mathrm{p}$.

MARTINS, FCO. and FERNANDES, VO., 2007. Estrutura da comunidade de algas perifíticas em substrato natural da lagoa da Universidade Federal do Espírito Santo, Brasil. Neotropical Biology and Conservation, São Leopoldo, vol. 2, no. 1, p. 11-20.

MATSUZAKI, M., MUCCI, JLN. and ROCHA, AA., 2004. Phytoplankton community in a recreational fishing lake, Brazil. Revista de Saúde Pública, vol. 38, no. 5, p. 679-686.

MELO, S. and HUSZAR, VLM., 2000. Phytoplankton in an Amazonian flood-plain lake (Lago Batata, Brasil): diel variation and species strategies. Journal of Plankton Research, vol. 22, no. 1, p. 63-76. http://dx.doi.org/10.1093/plankt/22.1.63

MURPHY, J., RILEY, JP.,1962. A modified single solution method for the determination of phosphate in natural waters. Analytica Chimica Acta, Amsterdam, vol. 27, p. 31-36.

NOGUEIRA, MG., 2000. Phytoplankton composition, dominance and abundance as indicators of environmental compartmentalization in Jurumirim Reservoir (Paranapanema River), São Paulo, Brazil. Hydrobiologia, Dordrecht, vol. 431, p. 115-128.

PADISÁK, J, BARBOSA, FAR, BORBÉLY, G., BORICS, G., CHORUS, I., ESPINDOLA, ELG., HEINZE, R. and ROCHA, O., 2000. Phytoplankton composition biodiversity and a pilot survey of toxic cyanoprokaryotas in a large cascading reservoir system (Tietê basin Brazil ), Verhandlungen des Internationalen Verein Limnologie, vol. 27 p. 2734-2742.

PINTO-COELHO, RM., 2004. Aporte de fósforo e a presença de cianobactérias no reservatório de São Simão. Belo Horizonte: Depto. Biologia Geral (ICB). 230p. Relatório Final - 6. Convênio CEMIG/FUNDEP.

PIVATO, BM., TRAIN, S. and RODRIGUES, L., 2006. Dinâmica nictemeral das assembléias fitoplanctônicas em um reservatório 
tropical (reservatório Corumbá, Estado de Goiás, Brasil), em dois períodos do ciclo hidrológico. Acta Scientiarum Biological Sciences, vol. 28, no. 1, p. 19-29.

PRYGIEL, J., 1991. Use of benthic diatoms in surveillance of the Artois-Picardie Basin hydrological quality. In WHITTON, BA., ROTT, E. and FRIEDRICH, G. (Eds.). Use of algae for monitoring rivers. Innsbruck: Institut fur Botanik, Universitat Innsbruck. p. 89-96.

REIS-PEREIRA, VL., 2002. Caracterização limnológica dos sistemas aquáticos da área e influência do aproveitamento hidroelétrico de Ipueiras - AHE Ipueiras-TO. Palmas: AHE Relatório Técnico.

REYNOLDS, CS., 1997. Vegetation process in the pelagic: a model for ecosystem theory. Oldendorf: Ecology Institute.

REYNOLDS, CS., HUSZAR, V., KRUK, C., NASELLI-FLORES, L. and MELO, S., 2002. Towards a functional classification of the freshwater phytoplankton. Journal of Plankton Research, vol. 24, no. 5, p. 417-428. http://dx.doi.org/10.1093/plankt/24.5.417

RODRIGUES, LC., TRAIN, S., PIVATO, BM., BOVO, VM., BORGES, PAF. and JATI, ES., 2005. Assembléias fitoplanctônicas de trinta reservatórios do Estado do Paraná. In RODRIGUES, L., THOMAZ, SM., AGOSTINHO, AA. and GOMES, LC. (Eds.). Biocenoses em reservatórios: padrões espaciais e temporais. São Carlos: RIMA. p. 57-72

SANT'ANNA, CL. and AZEVEDO, M.T.P., 2000. Contribution to the knowledge of potentially toxic Cyanobacteria from Brazil. Nova Hedwigia, vol. 71, p. 359-385.

SHANNON, CE. and WEAVER, WA., 1963. Mathematical theory of comunication. Urbana, Illinois: University Press.

SIEBURTH, JMcN., 1978. Bacterioplankton: Nature, biomass, activity, and relationships to the Protist plankton. Jornal of Phycology, vol. 14 (suppl.), p. 31.

SILVA, CA., TRAIN, S. and RODRIGUES, LC., 2001.Estrutura e dinâmica da comunidade fitoplânctonica a jusante e montante do reservatório de Corumbá, Caldas Novas, Estado de Goiás, Brasil. Acta Scientiarum Biological Sciences, vol. 23, no.2, p. 283-290.

-, 2005. Phytoplankton assemblages in a Brazilian subtropical cascading reservoir system. Hydrobiologia, vol. 537, p. 99-109. http://dx.doi.org/10.1007/s10750-004-2552-0

SOMMER, U., PADISÁK, J., REYNOLDS, LCS. and JUHÁSZNAGY, P., 1993. Hutchinson's heritage: the diversity-disturbance relationship in phytoplankton. Hydrobiologia, vol. 249, p. 1-7.
SOUZA, BDAS. and FERNANDES, VO., 2009. Estrutura e dinâmica da comunidade fitoplanctônica e sua relação com as variáveis ambientais na lagoa Mãe-Bá, Estado do Espírito Santo, Brasil. Acta Scientiarum Biological Sciences, Maringá, vol. 31, no. 3 , p. 245-253.

STRASKRABA, M., TUNDISI, J.G. and DUNCAN, A., 1993. A State-of-the-art of reservoir limnology and water quality management. In STRAŠKRABA, M., TUNDISI, JG., and DUNCAN, A. (Eds.). Comparative reservoir limnology and water quality management. Dordrecht: Kluwer Academic Press. p. 213-288. vol. 13.

Superintendências Regionais de Meio Ambiente e Desenvolvimento - SUPRAM, 2010. Parecer da solicitação de Licença de operação para PCH Malagone, instalada no rio Uberabinha. Cachoeira Dourada, Goiás: Relatório Técnico.

TER BRAAK, C.J.F. and SMILAUER, P. 2002. CANOCO reference manual and CanoDraw for Windows User's guide: Software for Canonical Community Ordination (version 4.5). Microcomputer Power, Ithaca NY. 352 p.

TRAIN, S., JATI, LC., RODRIGUES, L. and PIVATO, BM., 2005. Distribuição Espacial e Temporal do Fitoplâncton em Três Reservatórios da Bacia do Rio Paraná. In RODRIGUES, L., THOMAZ, SM., AGOSTINHO, AA. and GOMES, LC. (Eds.). Biocenoses em reservatórios: padrões espaciais e temporais. São Carlos: RIMA. p. 73-85.

TRAIN, S., RODRIGUES, LC., JATI, S., BORGES, PAF., BOVO, VM. and MARENGONI, E., 2006. Fitoplâncton. In AGOSTINHO, AA. (Coord.). Avaliação preliminar da viabilidade econômica e ambiental de cultivo de inverno de tilápia nilótica em tanques-rede. Maringá: Pronex, Nupelia, Universidade Estadual de Maringá. p. 107-110.

TUNDISI, JGT., MATSUMURA-TUNDISI, T. and ROCHA, O. 2002. Ecossistemas de águas interiores. In REBOUÇAS, AC., BRAGA, SB. and TUNDISI, J.G. Águas doces do Brasil: Capital Ecológico, uso e conservação. São Paulo.

UTHERMÖHL, H., 1958. Zur Vervollkomninung der quantitativen. Phytoplankton - Methodik. Mitteilungen Internationale Vereinigung fur Theoretische und Angewandte. Limnologie, vol. 9, p. 1-38.

WETZEL, RG. and LIKENS, GE., 2000. Limnological analysis. New York: Springer-Verlag,

ZALEWSKI, M., LOTKOWSKA-WAGNER, I. and TARCZYNSKA, M., 2000. Ecohydrological approaches to the elimination of toxic algal blooms in a lowland reservoir. Verhandlungen der Internationalen Vereinigung fur Limnologie, vol 27, p. 3176-3183. 